\title{
Opera as Literature and the Triumph of Music
}

\author{
Martin Adams
}

Many commentators have rightly seen dramatic opera (or semi-opera, as some persist in calling it) as primarily a literary genre. There has also been a tendency to attribute dramatic opera's separation of music from the main drama, and its confinement to certain kinds of function, to the taste of English audiences and, to a lesser extent, of dramatists. ${ }^{1}$

A major problem with this attribution to taste is that it tends to suppress thought. Taste, be it for certain kinds of drama, music or beer, is a faithful and factual manifestation of preference. But invoking it as a primary agent to explain dramatic opera gives insufficient credit to the creative and opinion-shaping powers of the dramatists involved; and it gives even less credit to the seventeenth-century English stage's cultivation of a sophisticated and distinctive role for music. The writings of seventeenth-century dramatists reveal that, although they acknowledged audience tastes, they often wished to shape them. Have great dramatists not always been like that?

A good starting point for an analysis of the dramaturgical and aesthetic concepts that gave rise to dramatic opera is Thomas Shadwell's (c. 1640-1692) 1675 musical drama, Psyche, a reworking of the 1671 French tragédie-ballet of the same name, which had a libretto by

\footnotetext{
${ }^{1}$ See, for example, Robert Etheridge Moore, Henry Purcell and the Restoration Theatre (Cambridge, Mass: Harvard University Press, 1961), pp. 95-97 exemplify the mode of argument.
} 
Molière, Corneille and Quinault, and music by Lully. Shadwell's composers were Matthew Locke (1621/3-1677), who wrote the vocal music, and the Italian-born, London-resident, Giovanni Battista Draghi (c. 1640-1708), who wrote most of the instrumental music.

Locke's music was published — the first such score of dramatic music in England. The title reads The English Opera, or the Vocal Musick in Psyche. This work, Locke declares, may justly wear the Title, though all the Tragedy be not in Musick: for the Author [i.e. Shadwell] prudently consider'd, that though Italy was, and is the great Academy of the World for that Science and way of Entertainment, England is not: and therefore mixt it with interlocutions, as more proper to our Genius. ${ }^{2}$

The crucial phrase here is 'proper to our Genius'; and we shall see that Locke's understanding of genius perforce incorporates a distinctive concept of taste, deeper than the dominant, thought-suppressing modern meaning — preference. For example, a recurrent seventeenth- and eighteenth-century meaning of genius is:

With reference to a nation, age, etc.: Prevalent feeling, opinion, sentiment, or taste; distinctive character, or spirit. ${ }^{3}$

Locke's understanding of taste as a component of genius embraces a meaning current from the middle of the seventeenth century until well into the nineteenth, but rarer now, except where we might say that someone's dress sense shows good taste. As the OED puts it, taste is:

\footnotetext{
${ }^{2}$ Matthew Locke, The English Opera, or The Vocal Musick in Psyche (London, 1675), unpaginated Preface. Early English Books Online. [Accessed 10 November 2012]

3 'genius, n.'. OED Online. September 2012. Oxford University Press. [Accessed November 10, 2012]
} 
The sense of what is appropriate, harmonious, or beautiful; esp. discernment and appreciation of the beautiful in nature or art; 4

So taste is an aesthetic concept that elevates value over mere preference, for it requires critical judgement, the assessment of what is and is not aesthetically excellent.

The descriptions of Psyche and other Restoration multi-media spectaculars, some of which predate it by up to twenty years, conform to what is perhaps the earliest definition of opera in an English dictionary. In Thomas Blount's (1618-1679) Glossographia of 1656, opera is described thus:

In Italy it signifies a Tragedy, Tragi-comedy, Comedy or Pastoral, which (being the studied work of a poet) is not acted after the vulgar manner, but performed by Voyces in that way, which the Italians term Recitative, being likewise adorned by Scenes by Perspective, and extraordinary advantages by Musick. ${ }^{5}$

Music might be seen as one component of a multi-media design; but English descriptions of opera, be they in dictionaries or in playbooks, prioritise dramatic poetry over all other elements, which are adornments.

This had been the case from the start, in the work of William Davenant (1606-1668), whose involvement in the masque — which had always been regarded as a literary genre, reached a pinnacle with the last Caroline court masque, Salmacida spolia (1640), notable for

\footnotetext{
4 'taste, n.'. OED Online. September 2012. Oxford University Press. [Accessed November 10, 2012]

5 Thomas Blount, Glossographia.( London: 1656) Early English Books Online. [Accessed 15 November 201]
} 
its spectacular scenery and stage effects. ${ }^{6}$ It was perhaps natural that Davenant, ever an artistic and commercial entrepreneur, should seek to give such spectacle a permanent footing in public theatre. ${ }^{7}$

In 1639, just two years after the opening of the world's first public opera house in Venice, a royal patent had been granted to

the said William Davenant ... from time to time to act Plays in such House, so to be by him or them erected, and exercise Musick, musical Presentments, Scenes, Dancing or other the like ... for the honest recreation of such as shall desire to see the same; 8

Davenant's plans were interrupted by the Civil War and the closure of theatres decreed by parliament in $1642{ }^{9}$ but in 1653 he published anonymously A Proposition for Advancement of Moralitie, By a new way of Entertainment of the People. In a calculated nod towards Puritan ethos and military power, and knowing that a revival of standard theatre was out of the question, the Proposition argued that this 'new way of entertainment' had potential to strengthen 'the principal ayds of Government' through an 'instructive Morality ... which is active and brought home to the senses.' 10

\footnotetext{
${ }^{6}$ For a discussion of the machinery and spectacle see John H. Astington, English Court Theatre, 1558-1642 (Cambridge: Cambridge University Press, 1999), especially pp. 142-160.

7 The spaces used for court theatre in England are discussed in Astington, English Court Theatre, Chapter 3.

${ }^{8}$ As in Thomas Rymer, Foedera, conventiones, literæ (London 1704-35) Vol. 20, pp. 377-378. Eighteenth-Century Collections Online. [Accessed 20 September 2012.]

${ }^{9}$ For Davenant's role in the masque and its impact on the later scenic stage in English, see Dawn Lewcock, Sir William Davenant, the Court Masque, and the English Seventeenth Century Scenic Stage, c. 1605-c. 1700 (London: Cambria Press, 2008).

10 [William Davenant] A Proposition for Advancement of Moralitie, By a new way of Entertainment of the People (London: 1654), p. 9. Early English Books Online. [Accessed 28 April 2013]
} 
Davenant's argument embraces the social, political and religious disputes that had constantly threatened the regime over the last decade or so, and declares theatre - an object of Puritan suspicion, to be

... a perfect means to retaine the people in quiet ... and that Persuasion must be joyn'd to Force, it can be compass'd no other way then by surprisall of their Eyes and Ears.... [having] their Eyes ... subdu'd with Heroicall Pictures and change of Scenes, their Ears civiliz'd with Musick and wholesome discourses,... to make a more natural resemblance of the great and vertuous Actions of such as are eminent in Story; ${ }^{11}$

To serve such lofty moral and civic purposes, the subjects of the entertainments were to be chosen so that

The chiefest objects represented, should be those famous Battels at Land and Sea by which this Nation is renown'd; presenting the Generals and other meritorious Leaders in their conduct, Dangers, Successes, and Triumphs; and the interlocution, between the changing of the Scenes, should be in praise of Valor, Vigilance, Military Painfulness, Temperance, and Obedience to Authority; $;^{12}$

\footnotetext{
${ }^{11}$ Ibid., pp. 11, 14.

12 Ibid., pp. 21-22
} 
Here we see a calculated distinction between categories. The senses, regarded with suspicion by so many Puritans, are to be controlled not by prohibition but by direction towards high virtues. Meaning is conveyed by 'wholesome discourses'. Scenes, machines and music heighten the impact via visual and aural representation of meaning.

That point is sustained in Davenant's public rehearsal of these arguments in The First Dayes Entertainment at Rutland House, By Declamations and Musick, which was staged in 1656 (the same year as Blount's Glossographia definition) in a large room behind his lodgings near the present-day Barbican Centre. At the opening of this sophisticated, dramatised dialogue in prose, 'the Prologue enters' and apologises for the smallness of the room, for the meagreness of the staging; and he looks forward, urging his audience to 'Think this your passage, and the narrow way / To our Elisian Field, the Opera'.13

The 'Elisian Field' was glimpsed in broader prospect when the four composers who had contributed to The First Dayes Entertainment - Charles Coleman (c. 1605-1664), Henry Cooke (c. 1615-1672), Henry Lawes (1596-1662) and George Hudson (d. 1672), were joined by a fifth, Matthew Lock, for the presentation later in 1656 of the first English opera, The Siege of Rhodes, Made a Representation by the Art of Prospective in Scenes, And the Story sung in Recitative Musick. ${ }^{14}$

\footnotetext{
${ }^{13}$ William Davenant, The First Dayes Entertainment at Rutland House, By Declamations and Musick: After the Manner of the Ancients (London: 1656), Prologue Early English Books Online [Accessed 21 December, 2012]

14 Title page of The Siege of Rhodes (London: 1656) Early English Books Online [Accessed 30 September 2012]
} 
Historical data surrounding The Siege of Rhodes is sufficiently complicated to have been subject to multiple interpretations. Some scholars, notably E.J. Dent, have argued that Davenant imagined it primarily as a play, and that the musical setting was an addition designed to evade the parliamentary ban on spoken theatre. ${ }^{15}$ This interpretation has proved remarkably persistent, despite scholarly arguments to the contrary over the last fifty years or so. ${ }^{16}$ This is not the place to rehearse the issues, except perhaps to observe that arguments in favour of The Siege being a originally a spoken play have generally failed to recognise the importance both of $A$ Proposition and of the patent granted to Davenant in 1639 and renewed, with minor alterations, after the Restoration. ${ }^{17}$

Despite a confused and confusing history, the survival of the complete text, plus detailed information about the 1656 staging, lend merit to the judgement of Philip Parsons (19261993) - whose experience as a theatre director as well as a distinguished academic gives his assessment a distinctive authority. Davenant's attempt to direct the senses towards reason hangs on a knife-edge. His method ... does not address the mind directly; it assaults it by way of the senses in a coordinated appeal— sculptural, painterly, musical, balletic, rhetorical. ${ }^{18}$

\footnotetext{
${ }^{15}$ Edward J. Dent, Foundations of English Opera: A Study of Musical Drama in England during the Seventeenth Century (Cambridge: Cambridge University Press, 1928), p. 65

${ }^{16}$ e.g. Dennis Arundell, A Critic at the Opera (London: E. Benn, 1957), p. 42; Robert Etheridge Moore, Henry Purcell and the Restoration Theatre, p. 28; Curtis Price, Henry Purcell and the London Stage (Cambridge: Cambridge University Press, 1984), pp. 39-40; James A. Winn, 'Heroic Song: A Proposal for a Revised History of English Theater and Opera, 1656-1711, Eighteenth-Century Studies 30/2 (1996/1997), 113-137, pp. 114-115

${ }^{17}$ For a helpful summary of the complexities surrounding The Siege of Rhodes, see James A. Winn, 'Heroic Song', pp. 116-120

${ }^{18}$ Philip Parsons, 'Restoration Tragedy as Total Theatre' in Harold Love (ed.), Restoration Literature: Critical Approaches (London: Methuen, 1972), 27-68, pp. 42-44.
} 
Coordination is perhaps the central concept here. But even if coordination produces some kind of balance of elements within this all-sung drama dominated by 'Recitative Musick', it does not necessarily dispel the tension between reason, embodied above all in the text, and the senses, to which music above all other elements has its primary appeal. Indeed, one of the most striking aspects of the development of dramatic opera is that its proponents seem deliberately to have eschewed the all-sung model precisely because they found a separation of music and spectacle to be the only way in which those tensions could be reconciled.

No playwright embodies those tensions more than John Dryden (1631-1700), England's greatest playwright and literary analyst from the last half of the seventeenth century, opera's sternest and most irreverent critic, yet the librettist for two of the largest and most important musical stage works of the century. Despite his oft-stated admiration for Davenant, and the fact that many of his plays include substantial musical scenes, Dryden's attitude towards opera as a multi-media entertainment was at best ambivalent, and sometimes outright hostile.

There is a revealing jibe in the Prologue and Epilogue Spoken at the Opening of the New House, March 26, 1674. This piece of characteristically fluid verse declared that the new theatre in Drury Lane would support English dramatists, and that 
'Twere folly now a stately pile to raise,

To build a playhouse, while you throw down plays;

Whilst scenes, machines, and empty operas reign, ${ }^{19}$

In this case Dryden had an agenda that was nationalistic, and in opposition to the other theatre company partly because that was not that company with which he had a contract to provide plays. Nevertheless, his view that opera, as he saw it practised, is empty, seems to have had deep roots. Nearly 20 years later, in the second of his important twin critical essays A Discourse on Satire (1692) and A Discourse on Epic Poetry (1697), he engages in a discussion of 'many things which the stage cannot or ought not to represent'. He declares that

Nothing but Nature can give a sincere pleasure; where that is not imitated, 'tis Grotesque Painting, the fine Woman ends in a Fish's Tail.

I might also add, that many things, which not only please, but are real Beauties in the reading, wou'd appear absurd upon the Stage; and those not only the Speciosa Miracula, as Horace calls them, of Transformations, of Scylla, Antiphates, and the Lestrygons, which cannot be represented even in Opera's, ${ }^{20}$

If we add this to a wider reading of Dryden's works, it seems clear that his primary concern about musical drama lay in an inherent tension between music's appeal to the

${ }^{19}$ John Dryden, 'Prologue and Epilogue Spoken at the Opening of the New House, March 26, 1674', Miscellany Poems (London: 1684) 286-290, p. 288. Early English Books Online [Accessed 27 April, 2013]

${ }^{20}$ A Satire on Epic Poetry (though not titled as such) first appeared as Dryden's prefatory essay dedicating his new translation of The Aeneid to John Sheffield (1648-1721), first Duke of Buckingham and Marquess of Normanby. John Dryden, The Words of Virgil, Containing His Pastorals, Georgics, and Aeneis. Translated into English Verse (London: 1697), unpaginated Dedication. Early English Books Online [Accessed 27 April 2013] 
senses, and the ideal propagated some years earlier in his Essay Of Dramatick Poesie (1668), that serious drama (as distinct from comedies) should be 'Nature wrought up to an higher pitch. ${ }^{21}$ Naturalness, reasonableness, realism - all heightened in impact by the power of spoken verse, are consistently praised. Understanding, not sensual pleasure, is the central aim.

So the power of music proper ranks lower than the different kind of musicality that defines the best dramatic verse. As Mark Van Doren declared many years ago, borrowing from a comment of Wordsworth, Dryden had an ear. ${ }^{22}$ With poetry that is itself so musical, music is either redundant or it threatens, because its sensuality subverts the elevated understanding that is a main aim of such verse.

Verse written for opera might be sung; but it should also be appropriate for reading in private - 'Beauties in the reading', as Dryden put it in his condemnation of opera. Thirty years earlier, the pragmatic Davenant had recognised the problem in the preface to The Siege of Rhodes:

You may inquire, being a Reader, why in an heroick Argument my numbers are so often diversify'd and fall into short fractions; considering that a continuation of the usual length of English verse would appear more Heroical in reading.

\footnotetext{
${ }^{21}$ John Dryden, Of Dramatick Poesie, An Essay (London: 1668), p. 66. Early English Books Online [Accessed 27 April 2013]

${ }^{22}$ Mark Van Doren, The Poetry of John Dryden, (New York: Harcourt, Brace and Howe, 1920). Reprinted as John Dryden: A Study of His Poetry (Bloomington: Indiana University Press, 1960), p. 253
} 
But ... frequent alterations of measure ... are necessary to Recitative Musick for variation of Ayres. ${ }^{23}$

A central challenge here is the pentameter's dominance in English dramatic verse - a dominance that by the 1650s had become far more comprehensive, whether the pentameter be blank verse or, as typically in Dryden until the late 1670s, the heroic couplet. It is no coincidence that when Dryden wrote verse designed from the start for musical setting in a non-dramatic context, such as the Cecilian odes From Harmony, From Heav'nly Harmony (1687), and Alexander's Feast (1697), he adopted much freer metrical designs..$^{24}$

When he did write dramatic verse designed for musical setting, notably in the all-sung royalist allegory Albion and Albanius, performed in1685, his struggles become obvious; and as James A. Winn has pointed out, Dryden's comments in the preface to that work are distinctly grumpy — even more so in its successor, King Arthur (1691). ${ }^{25}$ Dryden sense of taste (i.e. critical assessment) requires that musical drama withstand the same sustained judgement that he seeks for the spoken play — the kind of judgement to be discovered in reflective reading, because 'a judicious Reader will discover in his Closset that trashy stuffe, whose glittering deceived him in the action'.

\footnotetext{
${ }^{23}$ The Siege of Rhodes (London: 1656), Preface. Early English Books Online [Accessed 30 September 2012]

${ }^{24}$ This issue of poetic metre in dramatic opera has not received the attention it deserves. One of the few articles to address the issue is Andrew Pinnock \& Bruce Wood, 'A Mangled Chime: the accidental death of the opera libretto in civil war England', Early Music 36 (2008), 265-284.

${ }^{25}$ James A. Winn, 'Heroic Song', pp. 115-116.
} 
That last quotation comes from the dedicatory preface to Dryden's 1681 tragi-comedy The Spanish Fryar ${ }^{26}$, in the midst of a complaint about the effects of excessive action and spectacle on the stage.

In the Play-house everything contributes to impose upon the Judgement; the Lights, the Scenes, the Habits, and, above all, the Grace of Action, which is commonly the best where there is the most need of it, surprize the Audience, and cast a mist upon their Understandings; ${ }^{27}$

It seems safe to assume that music was under the same condemnation, that it was possibly even more central to tensions between, on one side the spectacular and the sensual, and on the other the literary and dramatic. These tensions were a source of published dispute for several decades after the Restoration, and a number of modern writers have pointed out that these disputes essentially concerned questions of value..$^{28}$

So Dryden's comments about these tensions are best understood as manifestations of taste in the highest sense - of a capacity for critical judgement in deciding what is appropriate to specific aesthetic functions. As Winn has pointed out, in a sensitive discussion of the relationships between verse, music and spectacle, Dryden's complaint is not inherently

\footnotetext{
${ }^{26}$ John Dryden, The Spanish Fryar (London: 1681), unpaginated Preface. Early English Books Online [Accessed 28 April 2013]

${ }^{27}$ Ibid.

${ }^{28}$ For an extended discussion of this issue, embracing the various constituencies of performers, theatre managers, playwrights and audiences, see Aparna Dharwadker, 'Authorship, Metatheatre, and Antitheatre in the Restoration', Theatre Research International 27 / 2 (2002), 125-135.
} 
anti-musical. ${ }^{29}$ It is rooted in an idealistic view of the power of dramatic verse when artfully declaimed.

In writing the all-sung Albion and Albanius Dryden tried hard to resolve this conundrum. But like Davenant before him, he writes a preface that apologises for the kind of verse he is supplying to the reader; and unlike Davenant, he is open about his reservations about opera.

The same Reasons which depress thought in an Opera, have a stronger effect upon the Words; especially in our language: For there is no maintaining the Purity of English in short Measures, where the Rhime returns so quick, ${ }^{30}$ English presents distinct challenges in writing verse suitable for music, qualities not to be found in the main verse forms of dramatic poetry. He has tried; but 'if there be no NorthEast Passage to be found, the fault is in Nature, and not in me.'31

Did Dryden have an ideal position? If he did, it seems likely that it is represented by The State of Innocence, a dramatised version of Milton's Paradise Lost, written in the classical five acts, mainly in rhyming heroic couplets, and which was published in 1677. It seems to be connected to the opening of the new Theatre Royal in $16744^{32}$ but it was never performed there or anywhere else.

\footnotetext{
${ }^{29}$ James A. Winn, 'Heroic Song', pp. 122-123

${ }^{30}$ John Dryden, Albion and Albanius: an Opera, or, Representation in Musick (London: 1687), unpaginated Preface.

${ }^{31}$ Ibid.

${ }^{32}$ James A. Winn, John Dryden and His World (New Haven, Conn.: 1987), pp. 262-4
} 
The title page reads The State of Innocence and Fall of Man: an Opera, Written in Heroique Verse; and the disposition of verse-types is revealing. In the few places where the main text is specified to be sung, the drama is not dealing with a dramatic discourse requiring understanding. These places are also those where Dryden most-often breaks away from the rhyming iambic pentameter, into the tetrameter or trimeter.

For example, in the first scene of Act III Adam and Eve are in Paradise; and while they sleep the stage direction declares that 'Lucifer sits down by Eve, and seems to whisper in her ear'.33 That sinister intervention triggers a dreamy, seductive sequence of dances and visions described in some detail, and all calculated to deceive the still-sleeping 'Fair Mother of Mankind' so that she will 'bless thy senses with the taste [of the forbidden fruit]'. The kind of music that accompanied these stage effects is not specified; but at some point during the sequence an Angel starts singing in dialogue with a 'Woman, habited like Eve'.

This scene and others in The State of Innocence embody many of the central characteristics of dramatic opera as it developed in the decades immediately after the Restoration. The spoken drama is in pentameter couplets; and as so often in art, the villain (Lucifer) gets some of the best. Music sets the scene, as in the moment of the Fall discussed above and many others. Temptation is delivered by Lucifer seeming to whisper into the ear of the

\footnotetext{
${ }^{33}$ John Dryden, The State of Innocence (London: 1677), p. 19. Early English Books Online [Accessed 27 September 2012]
} 
sleeping Eve; but temptation's seductive power is embodied in and accomplished by music, via singer-surrogates of both characters. Music is specified for various songs or dances, often while an effect of machinery is taking place. Almost all these specifications involve some kind of extremity, be it the opera's opening representation of 'a Chaos, or a confus'd Mass of Matter', or towards the end, when 'a Heaven descends, full of Angels and blessed Spirits'.

All this is consistent with the use of music and scenes in many plays by Dryden and others in the decades following the Restoration. But although that relationship between dramatic verse, spectacle and music has many precedents, The State of Innocence takes things onto a heightened level of musico-dramatic coherence. In so many ways the scenario described in Dryden's unperformed libretto is a prototype for all the dramatic operas that were performed from Dioclesian (1690) onwards. And the subject — the ultimate morality tale and the grandest heroic drama of them all, finds echoes in the moralising aspects of musical scenes in works such as King Arthur (1691) and The Fairy Queen (1692), and in several later dramatic operas for which composers other than Purcell provided the music.

The State of Innocence is an opera in every way that Restoration England understood that term. Yet, by its carefully calculated separation of dramatic verse (understanding) from music and spectacle (the senses), it fulfills all the main criteria that Dryden desires from spoken dramatic verse, both in performance and in private reading. It is surely significant that the published poem was advertised as an opera, that it sold well and was reprinted many times. Read as literature, it leaves vast space for the reader's imagination. 
Surely, this is a just yardstick for assessing the dramaturgical success or failure of dramatic opera. Does the work achieve that ideal raised by Davenant in his Proposition — that aural and visual representation can forcefully (or subtly) drive home a message explicated in spoken dramatic poetry? There seems no doubt that this was the ideal for which Dryden was aiming, for it is also essayed in King Arthur, or The British Worthy (1691), the most integrated of all the dramatic operas that were actually performed. (It was also the first dramatic opera to be called such by its author.)

Dryden's Arthur is the leader whose heroic virtue makes him alone worthy to lead his nation to its true destiny. After Arthur's army has overcome the Saxons in battle, the British Worthy must overcome on levels which become increasingly intimate. The last trial is in Act IV, when Arthur's enemies attempt the deceit and seduction of his very self through visions of beauty and desire — all accomplished in music. He encounters sexual temptation in the form of two half-naked sirens, and when he manages to ignore the blandishments of the duet 'Two Daughters of this Aged Stream' (and some other music, now lost), he encounters the immense passacaglia and dance 'How Happy the Lover'. This astonishing ground bass piece attempts to hypnotise Arthur through sheer persistence, to lead him into an illusion of love, to a lust which will destroy his noble character. But Arthur knows that he must mistrust not only music's sensuality, but his own; and because he possesses such noble virtue, he knows where the illusions come from. So at the end of the passacaglia he sends them back there — 'Fly after Night, and overtake the Moon'. 
The famous Frost Scene of Act III, where the evil Osmund tries to win over the virtuous Emmeline via a masque devoted to the power of love, is another example of music being given free rein only for its power as seducer to be usurped by the main characters' moral strength. The use of speech to articulate Arthur's and Emmeline's rejection of music's power as seducer is fine in the reading; and in performance it is bathetic only if stage production fails (as it usually does) to maintain a proper space between the worlds of understanding - embodied in the declamation of dramatic poetry, and sensual delight embodied in music and stage effects.

That space is critical to the all dramatic operas. The literary strengths of The Fairy Queen might be less than those of Shakespeare's original; but as Roger Savage has persuasively argued, the adapter of A Midsummer Night's Dream (probably Thomas Betterton) knew exactly what he was doing to facilitate the creation of such space. ${ }^{34}$ Music does not have to seduce - it can celebrate, it can evoke or be an instigator of magic, it can rouse warriors to valour, it can intensify the pains and pleasures of love. The list is endless.

It is revealing that when Dryden was excusing himself for writing the libretto to Albion and Albanius, he should explain the unusual nature of this entertainment in terms that apply to dramatic opera at least as much as they do to that all-sung piece:

Propriety of thought is that Fancy which arises naturally from the Subject, or which the Poet adapts to it. Propriety of Words, is the cloathing of those thoughts

\footnotetext{
${ }^{34}$ Roger Savage, 'The Shakespeare-Purcell "Fairy Queen": A Defence and Recommendation', Early Music 1/4 (1973), 200-221.
} 
with such Expressions, as are naturally proper to them: and from both these, if they are judiciously perform'd, the delight of Poetry results. ${ }^{35}$

Here is Dryden the critic and literary analyst declaring that although propriety — the 'sense of what is appropriate, harmonious, or beautiful'36 will vary from work to work, the artist achieves propriety through the exercise of imagination and craft. In Dryden's ideals, the miraculous powers of music are confined to places where miracles are acceptable because 'Human Impossibilities are to be received, as they are in Faith'. ${ }^{37}$ In the same place he addresses the dichotomy with which all dramatic opera must struggle, saying that 'the songish part' must 'abound in the oftness [i.e. frequency] and variety of numbers: its principal intention, being to please the hearing rather than to gratify the understanding'.

Later authors of dramatic opera sought to sustain such distinctions of province between music and drama; and there was little or no published criticism of the dramaturgical concept. (Roger North's oft-repeated complaints have been given too much weight..38)

When John Dennis (1658-1734) published An Essay on the Opera's After the Italian Manner in 1706, he was turning his fine critical mind to attacking Italian opera precisely because it prioritised music over the text. Dramatic opera was specifically exempted from his strictures, and not only because he had been the author of Rinaldo and Armida (1698), a

\footnotetext{
${ }^{35}$ John Dryden, Albion and Albanius, unpaginated Preface.

${ }^{36}$ See $n .4$ above.

${ }^{37}$ Dryden, Albion and Albanius, unpaginated Preface.

${ }^{38}$ See, for example, his oft-reported complaint that those who loved the play hated the music and vice versa. Roger North, The Musical Grammarian, ed. Mary Chan \& Jamie C. Kassler (Cambridge: Cambridge University Press, 1990), p. 267
} 
tragedy designed as a dramatic opera, with music by John Eccles (c. 1668-1735). His exemption is rooted in the same issues that had concerned Dryden, though expressed in a more vehement, nationalist tone:

Musick may be made profitable as well as delightful, if it is subordinate to some nobler Art, and subservient to Reason; but if it presumes ... to set up for itself, and to grow independent, as it does in our late Opera's, it becomes a meer sensual Delight, utterly incapable of informing the Understanding, or of reforming the Will. ${ }^{39}$

George Granville's dramatic opera The British Enchanters ... A Dramatick Poem, with Scenes, Machines, Musik, and Decorations, Ec. was staged in 1706 and published that same year. His Preface to the libretto is a mine of fascinating comparisons between English, French and Italian concepts of opera and drama; and recurrent themes are the importance of realism, the need for 'a skilful Mixture of the various Ingredients', and the need to keep a distinction between the musical and dramatic parts of the entertainment because they have distinct functions. So dramatic verse - and in Granville's case that means predominantly blank verse, must be spoken because ... if the Numbers are of themselves harmonious, there will be no need of Musick to set them off; a good Verse, well pronounced, is in it self musical; and Speech is certainly more natural for Discourse, than singing. ${ }^{40}$

\footnotetext{
${ }^{39}$ John Dennis, An Essay on the Opera's After the Italian Manner (London: 1706), p. 2. Eighteenth-Century Collections Online [Accessed 20 June 2012]

${ }^{40}$ George Granville, The British Enchanters: or No Magick like Love (London: 1706), unpaginated Preface. As in 1736 edn, Literature Online [Accessed 28 April 2013]
} 
French and Italian opera excel respectively in decorations and music. But ... the Drama falls short in both... An English Stomach requires something solid and substantial, and will rise hungary from a Regale of nothing but Sweetmeats. ${ }^{41}$

The robustly varied diet offered by dramatic opera was not suddenly swept away by the arrival of Italian opera in the 1710s. It declined gradually, but especially after theatre politics and finances dealt it a serious blow in 1708, with a decree from the Lord Chamberlain that the two main acting companies were to be merged at the theatre in Drury Lane, while the Haymarket was to have a monopoly on opera. ${ }^{42}$ The decline is also attributable partly, at least, to increasing modification of the 'skilful Mixture of the various Ingredients' in such revivals as did take place across that century. Increasingly, these revivals were instigated primarily because of the music. ${ }^{43}$

There is an odd kind of consistency in the fact that it was music — the area of the drama that Dryden, Granville and others sought to keep in its place because it was the most threatening to understanding and reason — which ultimately triumphed over drama. An ironic consequence of the separation between the provinces of drama and music (and spectacle) is that it left a special kind of other-space - one that a composer as ambitious

\footnotetext{
${ }^{41}$ Ibid.

${ }^{42}$ For a discussion of this most complicated issue, see Robert D. Hume, 'The Sponsorship of Opera in London, 1704-1720', Modern Philology 85/4 (1988), 420-432.

${ }^{43}$ For an account of one work's typical decline, see Ellen T. Harris, 'King Arthur's Journey into the Eighteenth Century', in Curtis Price, ed., Purcell Studies (Cambridge: Cambridge University Press, 1995), pp. 257-289
} 
and capable as Purcell could fill with music far more complex and sophisticated in design than anything in continental opera. ${ }^{44}$ The popular success of scenes such as the Frost Scene from King Arthur and the masques in The Fairy Queen was rooted as much in the sustained sensual beauties of their music as in their synthetic, high-Baroque relationship with the drama that they ornamented; and as high-Baroque culture was superseded by the eighteenth century's increasing rationalism, sensual delight became increasingly separated from the literary and dramatic context that gave it representative force. And as that went, so too did the specialised, judicious taste that had created a uniquely English form of musical drama. In that light, there is a certain logic to the success of Italian opera - an allmusical form of opera that evaded the need for understanding by being in a language many in the audience knew slightly or not at all, and presented by a composer, Handel, who at last could offer sensual delights to match those created by Purcell.

\footnotetext{
${ }^{44}$ See, for example, Martin Adams, Henry Purcell: the Origins and Development of His Musical Style (Cambridge: Cambridge University Press, 1995), pp. 297-301.
} 